\title{
Sonia Lamontagne
}

\section{I}

il chasse les cerfs-volants fuyants

de mes yeux

les chauves-souris pliantes

de mes grottes obscures

mon corps lui fait la grève

le sien me fait la cour

son sexe se lève

le mien ronfle

une paupière aux tissus musculaires

détendus

ses éveils contre mes silences

ses soleils contre mes nuits

ils se frottent l'un à l'autre

sans nous réchauffer

\section{II}

la vérité

il la dépose aussi légère

qu'un mouchoir usé

une colonie de mensonges jaune méchant

s'agglutine à mes pieds

monte jusqu'à mon cœur

il craque comme un œuf

la vérité me déplume

me décapite

m'ouvre le four

saute dedans

je suis une poule qui s'énerve

il m'a prise sous son aile

et derrière elle

une perruche que je ne connais pas 